\title{
Are US Inflation Expectations Re-Anchored?
}

\author{
Dieter Nautz* \\ Till Strohsal*
}

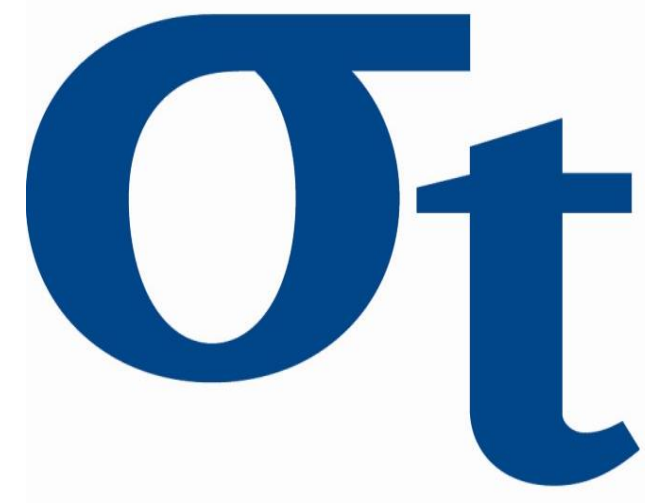

a

寸

6

* Freie Universität Berlin, Germany

This research was supported by the Deutsche Forschungsgemeinschaft through the SFB 649 "Economic Risk".

http://sfb649.wiwi.hu-berlin.de ISSN 1860-5664 


\title{
Are US Inflation Expectations Re-Anchored?
}

\author{
Dieter Nautz and Till Strohsal* \\ Freie Universität Berlin \\ Department of Economics \\ Boltzmannstr. 20, 14195 Berlin, Germany
}

October 15, 2014

Anchored inflation expectations are of key importance for monetary policy. If long-term inflation expectations are well-anchored, they should be unaffected by short-term economic news. This letter introduces newsregressions with multiple endogenous breaks to investigate the de- and re-anchoring of US inflation expectations. We confirm earlier evidence on the de-anchoring of expectations driven by the outbreak of the crisis. Our results indicate that expectations have not been re-anchored ever since.

Keywords: Anchoring of Inflation Expectations, Break-Even Inflation Rates, News-Regressions, Multiple Structural Break Tests

JEL classification: E31, E52, E58, C22

*Financial support from the Deutsche Forschungsgemeinschaft (DFG) through CRC 649 Economic Risk" is gratefully acknowledged.

E-mail: dieter.nautz@fu-berlin.de; till.strohsal@fu-berlin.de, phone: +49 (0)30 838-53399. 


\section{Introduction}

Anchoring of inflation expectations is of key importance for monetary policy. Yet, recent evidence suggests that US inflation expectations have been less anchored since the outbreak of the financial crisis, see e.g. Galati et al. (2011) and Autrup and Grothe (2014). Clearly, if inflation expectations are de-anchored they should be re-anchored as soon as possible. So far, however, it is not clear to what extent the crisis-related deanchoring of inflation expectations can be viewed as only a temporary phenomenon. In particular, the length of the de-anchoring period is unclear. Therefore, the current letter investigates whether US inflation expectations have been successfully reanchored over the recent years.

Firmly anchored inflation expectations should be unaffected by the release of economic news. News-regressions, where measures of expected inflation are regressed on news about inflation and other macroeconomic variables, are a widely used approach to test for the anchoring of inflation expectations, compare Levin et al. (2004) and Gürkaynak et al. (2005). ${ }^{1}$ Autrup and Grothe (2014) applied news-regressions and (exogenously) allowed for a de-anchoring of US inflation expectations in January 2008. Galati et al. (2011) estimate a single break (October 2008) in the newsregression and establish its significance using the endogenous break point test by

\footnotetext{
${ }^{1}$ The non-response to news should be seen as a necessary but not sufficient condition for anchored inflation expectations. Alternative approaches assess the anchoredness of inflation expectations from different perspectives, including the level, volatility and persistence of inflation expectations, compare Beechey et al. (2011) and Strohsal and Winkelmann (2014). News-regressions are estimated for changes of expected inflation implying that the level of expected inflation plays no particular role. Therefore, news-regressions are not distorted by a possible change in the central bank's inflation target, see Hördahl and Tristani (2014).
} 
Andrews (1993). Since our focus is on the possible re-anchoring of inflation expectations in the aftermath of the crisis, we have to account for multiple structural breaks. Therefore, we explore the time-varying responsiveness of expected inflation to news by use of various multiple endogenous break tests developed in Bai (1997) and Bai and Perron (1998).

Our empirical findings do not depend on the choice of the breakpoint test. First, all tests confirm earlier findings regarding the de-anchoring of US inflation expectations in the aftermath of the financial crisis. Second, none of the break point tests indicates a significant second break in our sample period. Therefore, the evidence obtained from news-regressions suggests that long-term inflation expectations are still de-anchored in the US.

The rest of our paper is structured as follows. Section 2 introduces the data for expected inflation derived from break-even inflation rates as well as the economic news variables. Section 3 briefly reviews the news-regression approach to anchoring inflation expectation and the multiple breakpoint tests. Section 4 shows our main empirical results and Section 5 concludes. 


\section{Data}

\subsection{Market based inflation expectations}

The growing market for inflation-linked securities have become an increasingly important source of information about expected inflation. Yields of index-linked and nominal bonds with equal maturity are used to derive the break-even inflation rate (BEI rates), i.e., the rate of inflation for which the payoff of the two types of bonds would be equal. In contrast to e.g. quarterly surveys of expected inflation, BEI rates are available at high frequency and are, therefore, particularly suitable to investigate how inflation expectations respond to economic news. The credibility of the central bank's commitment to maintaining price stability is particularly reflected in long-term inflation expectations implied by derived from implied forward breakeven inflation rates. In our empirical analysis, we focus on the one-year forward rate nine years ahead which has become a standard indicator for long-term inflation expectations, see e.g. Gürkaynak et al. (2010a) and Galati et al. (2011).

Liquidity conditions may affect the pricing of nominal and inflation-linked bonds and, thereby, the information content of BEI rates. For example, a higher trading volume in inflation-linked bonds may increase the break-even inflation rate only because it reduces the liquidity premium on inflation-linked bonds and, thereby, lowers the real yield. In line with e.g. Gürkaynak et al. (2010a), we obtain liquidityadjusted BEI rates by pre-filtering index-linked data based on common measures of liquidity risk. 
Figure 1 The Long-Run Forward Break-Even Inflation Rate in the US

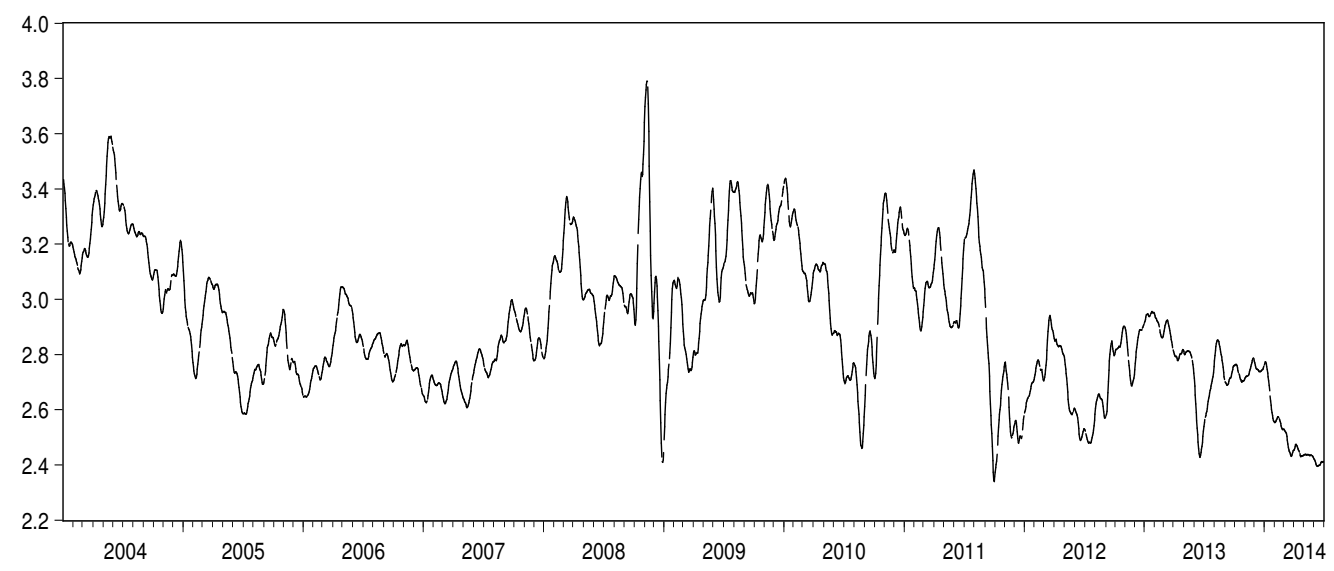

Notes: The figure shows the 1-year forward break-even rate 9 years ahead. Source: Federal Reserve Board staff, compare Gürkaynak et al. (2010b).

Our sample period starts in 2004 in order to ensure the availability of a sufficient number of index-linked bonds, see e.g. Gürkaynak et al. (2010b). ${ }^{2}$ The sample period ends in 6/30/2014 which allows to investigate whether inflation expectations have been re-anchored in the aftermath of the crisis. Data on break-even inflation rates are provided by the Federal Reserve Board staff (see also Gürkaynak et al. (2010b)), compare Figure 1. The relative trading volume of inflation-indexed bonds is taken from the Federal Reserve Bank of New York and and the corporate bond spread, a further proxy for liquidity conditions, is obtained from Datastream.

\footnotetext{
${ }^{2}$ In 2004, already 12 different inflation-indexed bonds are traded at the US secondary market. This number has almost tripled until today.
} 


\subsection{Economic news}

Following Gürkaynak et al. (2010a), the set of economic news variables includes surprises in economic activity (unemployment, advance GDP release, ISM manufacturing index, new home sales), prices (core CPI index,) and wages (nonfarm payrolls). These data are obtained from the Thomson Reuters IFR survey and are based on Wall Street economists' expectations of upcoming US economic reports. The news variable realizes at the day when the economic report is published and is defined as the actual value minus the median expectation. Thus, a higher-than-expected surprise would result in a positive realization of a news variable. To facilitate the interpretation of the estimated news-regression, we normalize the surprise variables by their standard deviation. Finally, monetary policy surprises are measured as percentage point changes in the 30-day T-bill rate at the monetary policy announcement day. Accordingly, a positive realization of the surprise variable would indicate that monetary policy is tighter than expected.

\section{News-Regressions with Multiple Breaks}

We investigate the time-varying degree of anchoring of inflation expectations using the following news-regression with multiple breaks,

$$
\Delta \pi_{t}^{\mathrm{e}}=\alpha+\beta_{i}^{\prime} X_{t}+\varepsilon_{t}, i=1, \ldots, l+1 .
$$


where $\Delta \pi_{t}^{\mathrm{e}}$ denotes the daily change of long-term inflation expectations and $X_{t}$ contains the set of economic news variables. Since the degree of the anchoring of inflation expectations may be subject to regime changes, the vector of coefficients $\beta$ may break $l$ times which gives us $l+1$ regimes. Inflation expectations are anchored in regime $i$ if the news-coefficients $\beta_{i}$ are jointly zero.

The testing theory for multiple endogenous breaks has been developed by Bai (1997), Bai and Perron (1998), Bai and Perron (2003b), Bai and Perron (2003a). ${ }^{3}$ For sake of robustness, we consider several variants of multiple break tests. Each variant builds on the sum of squared residuals

$$
\sum_{i=1}^{l+1} \sum_{t=T_{i-1}+1}^{T_{i}}\left(\Delta \pi_{t}^{\mathrm{e}}-\hat{\alpha}-\hat{\beta}_{i}^{\prime} X_{t}\right)^{2}
$$

( $T_{0}=0$ and $T_{l+1}=T$ ) and is based on the corresponding F-statistic

$$
F\left(T_{1}, \ldots, T_{l} ; q\right)=\frac{1}{T}\left(\frac{T-(l+1) q-p}{l}\right) \hat{\beta}^{\prime} R^{\prime}\left(R \hat{V}(\hat{\beta}) R^{\prime}\right)^{-1} R \hat{\beta}
$$

where $\mathrm{V}(\hat{\beta})$ is a heteroscedasticity and autocorrelation consistent estimate of the covariance matrix of breaking regression coefficients. $R$ is defined such that $R \hat{\beta}=$ $\left(\hat{\beta}_{1}^{\prime}-\hat{\beta}_{2}^{\prime}, \ldots, \hat{\beta}_{l}^{\prime}-\hat{\beta}_{l+1}^{\prime}\right)$, and $q$ and $p$ denote the numbers of breaking and nonbreaking coefficients, respectively. Apparently, the F-statistic increases and an additional break date becomes more likely, if differences between estimated coefficients of adjacent regimes are large. Bai and Perron (2003b) provide simulated critical values for the following variants of the tests.

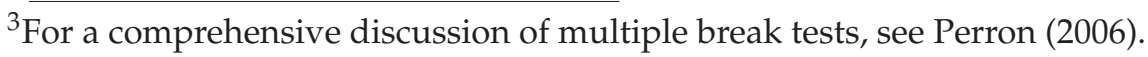


In the first step of the sequential test, the F-statistic is used to test for a single break over the full sample. The natural breakpoint candidate is the date that reduces the sum of squared residuals most. Provided that the break is found to be significant, the procedure is repeated for both regimes to identify a possible second break date. The sequential testing procedure stops until the null of no break cannot be rejected. In the global test, optimization is performed along both dimensions, the number of breakpoints and the break dates. Bai and Perron (2003a) propose an efficient algorithm to reduce the computational burden of the global test considerably. ${ }^{4}$ Finally, we use the combined break test proposed by Bai and Perron (1998). In this variant, $l$ is determined globally and sequential tests for additional breaks are conducted in each of the $l+1$ regimes.

In our empirical application, we allow for up to $l^{*}=3$ structural breaks implying up to 4 different anchoring regimes. Note that this choice covers the case of 3 regimes referring to periods of anchored, de-anchored and re-anchored inflation expectations. We trim $10 \%$ of the observations at the boundaries of each regime. This implies a minimum regime length of 12 [6] months in case of $l=1$ [2] breaks.

\footnotetext{
${ }^{4}$ For the global test, Bai and Perron (1998) propose two versions of the test statistic, UD $\mathrm{Dax}_{\text {ax }}$ and $\mathrm{WD}_{\max }$. UD $\mathrm{D}_{\max }$ assigns equal weights implying that each number of breaks is considered equally likely. $\mathrm{WD}_{\max }$ uses weights which improve the power of the test when the true number of breaks is higher than the number of breaks under the null.
} 


\section{The Time-Varying Degree of Anchoring of Inflation}

\section{Expectations}

Let us first investigate whether the response of long-term inflation expectations to economic news has changed over time. Table 1 summarizes our results obtained from multiple endogenous structural break tests. Irrespective of the underlying test variant, there is clear evidence for a single break in the news-regression. For each test, the suggested break date is 07/01/2009 which is line with the crisis-related de-anchoring of inflation expectations found by Galati et al. (2011) and Autrup and Grothe (2014). However, none of the tests provide any evidence, not even at the $10 \%$ level, for the existence of an additional break, i.e., for a possible re-anchoring.

Table 1 Regimes of Anchoring of Inflation Expectations: Results from Endogenous Break Tests

\begin{tabular}{l|cccc|ccc|ccc}
$\begin{array}{l}\text { multiple break } \\
\text { test variant }\end{array}$ & $\begin{array}{l}\text { breaks }(l) \\
\text { under } \mathrm{H}_{1}\end{array}$ & $\begin{array}{c}\text { test } \\
\text { statistic }\end{array}$ & $\begin{array}{c}5 \% \text { crit. } \\
\text { value }\end{array}$ & break date & $\begin{array}{l}\text { breaks }(l) \\
\text { under } \mathrm{H}_{1}\end{array}$ & $\begin{array}{c}\text { test } \\
\text { statistic }\end{array}$ & $\begin{array}{c}10 \% \text { crit. } \\
\text { value }\end{array}$ & $\begin{array}{l}\text { breaks }(l) \\
\text { under } \mathrm{H}_{1}\end{array}$ & $\begin{array}{c}\text { test } \\
\text { statistic }\end{array}$ & $\begin{array}{c}10 \% \text { crit. } \\
\text { value }\end{array}$ \\
\hline global $\left(\mathrm{UD}_{\max }\right)$ & 1 & 25.49 & 21.46 & $07 / 01 / 2009$ & 2 & 12.82 & 19.30 & 3 & 14.81 & 19.30 \\
global $\left(\mathrm{WD}_{\max }\right)$ & 1 & 25.49 & 22.76 & $07 / 01 / 2009$ & 2 & 14.70 & 20.56 & 3 & 19.57 & 20.56 \\
sequential & 1 & 25.49 & 21.33 & $07 / 01 / 2009$ & 2 & 18.41 & 21.24 & -- & -- & -- \\
combined & 1 & 25.49 & 21.33 & $07 / 01 / 2009$ & 2 & 18.41 & 21.24 & 3 & 21.30 & 22.42 \\
\hline
\end{tabular}

Notes: Results of multiple structural break tests for the news-regression (1). Critical values are taken from Bai and Perron (2003b). global ( $\left.\mathrm{UD}_{\max }\right)$ and global (WD $\left(\mathrm{D}_{\max }\right)$ refer to the global testing procedures described in Bai and Perron (1998). The sequential test is introduced by Bai (1997). For the combined testing approach, see Bai and Perron (1998). In each panel, the columns provide the number of breaks $(l)$ under $H_{1}$, followed by the robust test statistic, the relevant critical value, and - in case of significance $(l=1)$ — the estimated break date. According to $10 \%$ critical values (shown for $l=2,3$ ), all tests indicate a single break in July 2009.

Table 2 presents the estimated coefficients of the news-regression that accounts for the structural break found in 07/01/2009. Before the break, the response of inflation expectations to economic news is typically small and insignificant. The only exception refers to the coefficient of New Home Sales. According to the $p$-value of the test for the joint significance of economic news $(p=0.59)$, inflation expectations 
were well-anchored during the pre-crisis period. However, estimates look rather different for the second period, i.e. after the break. For many of the news variables, both size and significance of the estimated coefficients increased. The increasing role of economic news for inflation expectations is also reflected in the test for joint significance which is now statistically significant at any conventional confidence level. As a consequence, the estimation results confirm earlier concerns regarding a crisisrelated de-anchoring of inflation expectations in the US. Unfortunately, our findings do not indicate that inflation expectations have been successfully re-anchored ever since.

Table 2 The Time-Varying Response of Inflation Expectations to Economic News

\begin{tabular}{|c|c|c|c|c|c|c|c|}
\hline before break & CPI & Unemployment & GDP & ISM & New Home Sales & Nonfarm Payrolls & Monetary Policy \\
\hline$\Delta \pi_{t}^{\mathrm{e}}$ & $\begin{array}{l}0.13 \\
(0.81)\end{array}$ & $\begin{array}{l}0.11 \\
(0.90)\end{array}$ & $\begin{array}{r}-0.00 \\
(0.99)\end{array}$ & $\begin{array}{l}0.18 \\
(0.61)\end{array}$ & $\begin{array}{l}0.42 \\
(0.05)\end{array}$ & $\begin{array}{r}-0.93 \\
(0.35)\end{array}$ & $\begin{array}{r}-0.19 \\
(0.68)\end{array}$ \\
\hline \multirow[t]{2}{*}{ diagnostics } & joint test & $R^{2}$ & DW & \# of obs. & & & \\
\hline & $\begin{array}{l}0.80 \\
(0.59)\end{array}$ & 0.01 & 2.50 & 1376 & & & \\
\hline $\begin{array}{l}\text { news-regression } \\
\text { after break }\end{array}$ & CPI & Unemployment & GDP & ISM & New Home Sales & Nonfarm Payrolls & Monetary Policy \\
\hline$\Delta \pi_{t}^{\mathrm{e}}$ & $\begin{array}{r}-0.51 \\
(0.33)\end{array}$ & $\begin{array}{r}-0.17 \\
(0.64)\end{array}$ & $\begin{array}{l}2.39 \\
(0.00)\end{array}$ & $\begin{array}{l}1.10 \\
(0.07)\end{array}$ & $\begin{array}{r}-1.53 \\
(0.06)\end{array}$ & $\begin{array}{l}0.55 \\
(0.04)\end{array}$ & $\begin{array}{l}5.51 \\
(0.10)\end{array}$ \\
\hline \multirow[t]{2}{*}{ diagnostics } & joint test & $R^{2}$ & DW & \# of obs. & & & \\
\hline & $\begin{array}{l}4.55 \\
(0.00)\end{array}$ & 0.04 & 2.57 & 1249 & & & \\
\hline
\end{tabular}

Endogenous break point tests have difficulties to identify regime changes at the boundaries of the sample period. In our case, the required trimming of the data implies that a second break point probably indicating the re-anchoring of inflation expectations has to be found until the end of 2013. What if re-anchoring has actually taken place but tests are simply not powerful enough to detect a second break 
in the news-regression? To shed more light on this issue, we re-estimated the newsregression accounting for the most likely (but still insignificant) second break date. All test variants suggest the $03 / 17 / 2011$ as the start of the third regime. Table 3 shows the results of the news-regression for that period. While inflation expectations are not fully re-anchored, the importance of economic news has decreased. This might indicate that monetary policy is back on track to regain its credibility.

Table 3 What if there was a Second Break? Some Evidence towards a Re-Anchoring

\begin{tabular}{|c|c|c|c|c|c|c|c|}
\hline of re-anchoring & CPI & Unemployment & GDP & ISM & New Home Sales & Nonfarm Payrolls & Monetary Policy \\
\hline$\Delta \pi_{t}^{\mathrm{e}}$ & $\begin{array}{r}-0.20 \\
(0.67)\end{array}$ & $\begin{array}{l}0.25 \\
(0.52)\end{array}$ & $\begin{array}{l}1.46 \\
(0.02)\end{array}$ & $\begin{array}{l}0.10 \\
(0.84)\end{array}$ & $\begin{array}{r}-0.84 \\
(0.36)\end{array}$ & $\begin{array}{c}0.83 \\
(0.00)\end{array}$ & $\begin{array}{l}2.38 \\
(0.47)\end{array}$ \\
\hline \multirow[t]{2}{*}{ diagnostics } & joint test & $R^{2}$ & DW & \# of obs. & & & \\
\hline & $\begin{array}{l}1.74 \\
(0.11)\end{array}$ & 0.01 & 2.49 & 822 & & & \\
\hline
\end{tabular}

\section{Conclusion}

We provided new evidence on the anchoring of US long-term inflation expectations. A necessary condition for firmly anchored long-term inflation expectations is that they are unaffected by short-term economic news. In order to control for a changing degree of anchoring, we employed news-regressions with multiple endogenous break points. Our results clearly indicate that US long-term inflation expectations were less-anchored in the aftermath of the financial crisis. The de-anchoring of inflation expectations, however, might be not only a temporary phenomenon. Even 
several years after the Lehman breakdown, the evidence in favor of re-anchored inflation expectations remains only weak.

\section{References}

Andrews, D. W. K. (1993). Tests for parameter instability and structural change with unknown change point. Econometrica, 61(4):pp. 821-856.

Autrup, S. L. and Grothe, M. (2014). Economic surprises and inflation expectations: Has anchoring of expectations survived the crisis? European Central Bank Working Paper Series, 1671.

Bai, J. (1997). Estimating multiple breaks one at a time. Econometric Theory, 13(3):pp. 315-352.

Bai, J. and Perron, P. (1998). Estimating and testing linear models with multiple structural changes. Econometrica, 66(1):pp. 47-78.

Bai, J. and Perron, P. (2003a). Computation and analysis of multiple structural change models. Journal of Applied Econometrics, 18(1):1-22.

Bai, J. and Perron, P. (2003b). Critical values for multiple structural change tests. The Econometrics Journal, 6(1):pp. 72-78.

Beechey, M. J., Johannsen, B. K., and Levin, A. T. (2011). Are long-run inflation expectations anchored more firmly in the euro area than in the united states? American Economic Journal: Macroeconomics, 3(2):pp. 104-129.

Galati, G., Poelhekke, S., and Zhou, C. (2011). Did the crisis affect inflation expectations? International Journal of Central Banking, 7(1):167-207.

Gürkaynak, R. S., Levin, A., and Swanson, E. (2010a). Does inflation targeting anchor long-run inflation expectations? evidence from the u.s., uk, and sweden. Journal of the European Economic Association, 8(6):1208-1242.

Gürkaynak, R. S., Sack, B., and Swanson, E. (2005). The sensitivity of long-term interest rates to economic news: Evidence and implications for macroeconomic models. The American Economic Review, 95(1):pp. 425-436.

Gürkaynak, R. S., Sack, B., and Wright, J. H. (2010b). The tips yield curve and inflation compensation. American Economic Journal: Macroeconomics, 2(1):pp. 70-92.

Hördahl, P. and Tristani, O. (2014). Inflation risk premia in the euro area and the united states. International Journal of Central Banking, 10(3). 
Levin, A. T., Natalucci, F. M., and Piger, J. (2004). Explicit inflation objectives and macroeconomic outcomes. European Central Bank Working Paper Series, 383.

Perron, P. (2006). Dealing with structural breaks. In Palgrave Handbook of Econometrics, Vol. 1: Econometric Theory, T. C. Mills and K. Patterson (eds.), pages 278-352.

Strohsal, T. and Winkelmann, L. (2014). Assessing the anchoring of inflation expectations. Journal of International Money and Finance, forthcoming. 


\section{SFB 649 Discussion Paper Series 2014}

For a complete list of Discussion Papers published by the SFB 649, please visit http://sfb649.wiwi.hu-berlin.de.

001 "Principal Component Analysis in an Asymmetric Norm" by Ngoc Mai Tran, Maria Osipenko and Wolfgang Karl Härdle, January 2014.

002 "A Simultaneous Confidence Corridor for Varying Coefficient Regression with Sparse Functional Data" by Lijie Gu, Li Wang, Wolfgang Karl Härdle and Lijian Yang, January 2014.

003 "An Extended Single Index Model with Missing Response at Random" by Qihua Wang, Tao Zhang, Wolfgang Karl Härdle, January 2014.

004 "Structural Vector Autoregressive Analysis in a Data Rich Environment: A Survey" by Helmut Lütkepohl, January 2014.

005 "Functional stable limit theorems for efficient spectral covolatility estimators" by Randolf Altmeyer and Markus Bibinger, January 2014.

006 "A consistent two-factor model for pricing temperature derivatives" by Andreas Groll, Brenda López-Cabrera and Thilo Meyer-Brandis, January 2014.

007 "Confidence Bands for Impulse Responses: Bonferroni versus Wald" by Helmut Lütkepohl, Anna Staszewska-Bystrova and Peter Winker, January 2014.

008 "Simultaneous Confidence Corridors and Variable Selection for Generalized Additive Models" by Shuzhuan Zheng, Rong Liu, Lijian Yang and Wolfgang Karl Härdle, January 2014.

009 "Structural Vector Autoregressions: Checking Identifying Long-run Restrictions via Heteroskedasticity" by Helmut Lütkepohl and Anton Velinov, January 2014.

010 "Efficient Iterative Maximum Likelihood Estimation of HighParameterized Time Series Models" by Nikolaus Hautsch, Ostap Okhrin and Alexander Ristig, January 2014.

011 "Fiscal Devaluation in a Monetary Union" by Philipp Engler, Giovanni Ganelli, Juha Tervala and Simon Voigts, January 2014.

012 "Nonparametric Estimates for Conditional Quantiles of Time Series" by Jürgen Franke, Peter Mwita and Weining Wang, January 2014.

013 "Product Market Deregulation and Employment Outcomes: Evidence from the German Retail Sector" by Charlotte Senftleben-König, January 2014.

014 "Estimation procedures for exchangeable Marshall copulas with hydrological application" by Fabrizio Durante and Ostap Okhrin, January 2014.

015 "Ladislaus von Bortkiewicz - statistician, economist, and a European intellectual" by Wolfgang Karl Härdle and Annette B. Vogt, February 2014.

016 "An Application of Principal Component Analysis on Multivariate TimeStationary Spatio-Temporal Data" by Stephan Stahlschmidt, Wolfgang Karl Härdle and Helmut Thome, February 2014.

017 "The composition of government spending and the multiplier at the Zero Lower Bound" by Julien Albertini, Arthur Poirier and Jordan RoulleauPasdeloup, February 2014.

018 "Interacting Product and Labor Market Regulation and the Impact of Immigration on Native Wages" by Susanne Prantl and Alexandra SpitzOener, February 2014.

\section{SFB 649, Spandauer Straße 1, D-10178 Berlin http://sfb649.wiwi.hu-berlin.de}

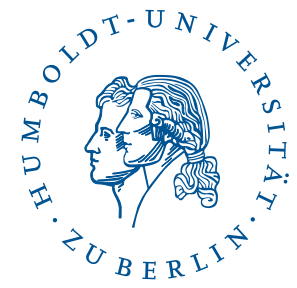




\title{
SFB 649 Discussion Paper Series 2014
}

\author{
For a complete list of Discussion Papers published by the SFB 649, \\ please visit http://sfb649.wiwi.hu-berlin.de.
}

019 "Unemployment benefits extensions at the zero lower bound on nominal interest rate" by Julien Albertini and Arthur Poirier, February 2014.

020 "Modelling spatio-temporal variability of temperature" by Xiaofeng Cao, Ostap Okhrin, Martin Odening and Matthias Ritter, February 2014.

021 "Do Maternal Health Problems Influence Child's Worrying Status? Evidence from British Cohort Study" by Xianhua Dai, Wolfgang Karl Härdle and Keming Yu, February 2014.

022 "Nonparametric Test for a Constant Beta over a Fixed Time Interval" by Markus Reiß, Viktor Todorov and George Tauchen, February 2014.

023 "Inflation Expectations Spillovers between the United States and Euro Area" by Aleksei Netšunajev and Lars Winkelmann, March 2014.

024 "Peer Effects and Students' Self-Control" by Berno Buechel, Lydia Mechtenberg and Julia Petersen, April 2014.

025 "Is there a demand for multi-year crop insurance?" by Maria Osipenko, Zhiwei Shen and Martin Odening, April 2014.

026 "Credit Risk Calibration based on CDS Spreads" by Shih-Kang Chao, Wolfgang Karl Härdle and Hien Pham-Thu, May 2014.

027 "Stale Forward Guidance" by Gunda-Alexandra Detmers and Dieter Nautz, May 2014.

028 "Confidence Corridors for Multivariate Generalized Quantile Regression" by Shih-Kang Chao, Katharina Proksch, Holger Dette and Wolfgang Härdle, May 2014.

029 "Information Risk, Market Stress and Institutional Herding in Financial Markets: New Evidence Through the Lens of a Simulated Model" by Christopher Boortz, Stephanie Kremer, Simon Jurkatis and Dieter Nautz, May 2014.

030 "Forecasting Generalized Quantiles of Electricity Demand: A Functional Data Approach" by Brenda López Cabrera and Franziska Schulz, May 2014.

031 "Structural Vector Autoregressions with Smooth Transition in Variances The Interaction Between U.S. Monetary Policy and the Stock Market" by Helmut Lütkepohl and Aleksei Netsunajev, June 2014.

032 "TEDAS - Tail Event Driven ASset Allocation" by Wolfgang Karl Härdle, Sergey Nasekin, David Lee Kuo Chuen and Phoon Kok Fai, June 2014.

033 "Discount Factor Shocks and Labor Market Dynamics" by Julien Albertini and Arthur Poirier, June 2014.

034 "Risky Linear Approximations" by Alexander Meyer-Gohde, July 2014

035 "Adaptive Order Flow Forecasting with Multiplicative Error Models" by Wolfgang Karl Härdle, Andrija Mihoci and Christopher Hian-Ann Ting, July 2014

036 "Portfolio Decisions and Brain Reactions via the CEAD method" by Piotr Majer, Peter N.C. Mohr, Hauke R. Heekeren and Wolfgang K. Härdle, July 2014

037 "Common price and volatility jumps in noisy high-frequency data" by Markus Bibinger and Lars Winkelmann, July 2014

038 "Spatial Wage Inequality and Technological Change" by Charlotte Senftleben-König and Hanna Wielandt, August 2014

039 "The integration of credit default swap markets in the pre and postsubprime crisis in common stochastic trends" by Cathy Yi-Hsuan Chen, Wolfgang Karl Härdle, Hien Pham-Thu, August 2014

\section{SFB 649, Spandauer Straße 1, D-10178 Berlin http://sfb649.wiwi.hu-berlin.de}

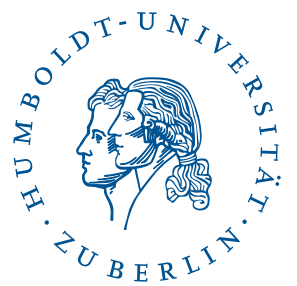




\title{
SFB 649 Discussion Paper Series 2014
}

\author{
For a complete list of Discussion Papers published by the SFB 649, \\ please visit http://sfb649.wiwi.hu-berlin.de.
}

040 "Localising Forward Intensities for Multiperiod Corporate Default" by Dedy Dwi Prastyo and Wolfgang Karl Härdle, August 2014.

041 "Certification and Market Transparency" by Konrad Stahl and Roland Strausz, September 2014.

042 "Beyond dimension two: A test for higher-order tail risk" by Carsten Bormann, Melanie Schienle and Julia Schaumburg, September 2014.

043 "Semiparametric Estimation with Generated Covariates" by Enno Mammen, Christoph Rothe and Melanie Schienle, September 2014.

044 "On the Timing of Climate Agreements" by Robert C. Schmidt and Roland Strausz, September 2014.

045 "Optimal Sales Contracts with Withdrawal Rights" by Daniel Krähmer and Roland Strausz, September 2014.

046 "Ex post information rents in sequential screening" by Daniel Krähmer and Roland Strausz, September 2014.

047 "Similarities and Differences between U.S. and German Regulation of the Use of Derivatives and Leverage by Mutual Funds - What Can Regulators Learn from Each Other?" by Dominika Paula Gałkiewicz, September 2014.

048 "That's how we roll: an experiment on rollover risk" by Ciril Bosch-Rosa, September 2014.

049 "Comparing Solution Methods for DSGE Models with Labor Market Search" by Hong Lan, September 2014.

050 "Volatility Modelling of CO2 Emission Allowance Spot Prices with RegimeSwitching GARCH Models" by Thijs Benschop, Brenda López Cabrera, September 2014.

051 "Corporate Cash Hoarding in a Model with Liquidity Constraints" by Falk Mazelis, September 2014.

052 "Designing an Index for Assessing Wind Energy Potential" by Matthias Ritter, Zhiwei Shen, Brenda López Cabrera, Martin Odening, Lars Deckert, September 2014.

053 "Improved Volatility Estimation Based On Limit Order Books" by Markus Bibinger, Moritz Jirak, Markus Reiss, September 2014.

054 "Strategic Complementarities and Nominal Rigidities" by Philipp König, Alexander Meyer-Gohde, October 2014.

055 "Estimating the Spot Covariation of Asset Prices - Statistical Theory and Empirical Evidence" by Markus Bibinger, Markus Reiss, Nikolaus Hautsch, Peter Malec, October 2014.

056 "Monetary Policy Effects on Financial Intermediation via the Regulated and the Shadow Banking Systems" by Falk Mazelis, October 2014.

057 "A Tale of Two Tails: Preferences of neutral third-parties in three-player ultimatum games" by Ciril Bosch-Rosa, October 2014.

058 "Boiling the frog optimally: an experiment on survivor curve shapes and internet revenue" by Christina Aperjis, Ciril Bosch-Rosa, Daniel Friedman, Bernardo A. Huberman, October 2014.

058 "Expectile Treatment Effects: An efficient alternative to compute the distribution of treatment effects" by Stephan Stahlschmidt, Matthias Eckardt, Wolfgang K. Härdle, October 2014.

060 "Are US Inflation Expectations Re-Anchored?" by Dieter Nautz, Till Strohsal, October 2014.

\section{SFB 649, Spandauer Straße 1, D-10178 Berlin http://sfb649.wiwi.hu-berlin.de}

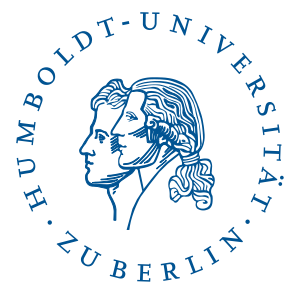

